\title{
Designing Power Optimization Strategy for Sustainable Operations of Distribution Companies in Rajasthan
}

\author{
Amit Kumar Sharma ${ }^{1 *}$; Dr Dipti Sharma² \\ ${ }^{I}$ Research Scholar, Department of Humanities and Social Sciences, Malaviya National Institute of Technology, \\ Jaipur (Rajasthan, India),Email Id: 2016rhs9014@mnit.ac.in \\ ${ }^{2}$ Associate Professor, Department of Humanities and Social Sciences, Malaviya National Institute of \\ Technology, Jaipur (Rajasthan, India),Email Id: dsharma.hum@mnit.ac.in \\ *Corresponding Author: 2016rhs9014@mnit.ac.in
}

\begin{abstract}
The Indian power sector is undergoing a structural change through a series of reforms initiated during the last two decades. The Electricity Act, 2003 have transformed the way the power utilities operate in India. The majority of reforms have stressed upon the measures for improvement of the finances of the power distribution companies (Discoms), however with little success. The stressed finances have impacted the sustainable operations of the distribution utilities. Among all the distribution companies in India, the Discoms of Rajasthan were the worst performers as per the $5^{\text {th }}$ Annual Integrated Rating Report, 2017. One of the major reason of this has been the high power purchase cost. The present study aims to design a strategy to reduce the cost of power purchase through participation in the short term power market. The reduction in the power purchase cost will pave way for sustainable operations of Discoms in Rajasthan. This paper attempts to build scenarios of power being procured from long term and short term power purchase agreements (PPAs) which are compared and analysed. The findings reveal that increase in the proportion of power procured from the short term power market can decrease the financial losses of the Discoms in Rajasthan and will address the sustainability issue of the distribution utilities. The study concludes that the power purchased from the long term sources is costly as compared to the short term power sources. The key recommendation from this study to policy makers is to increase participation in the short term market in India, which will reduce the overall power purchase cost. The limitation of the study is that all the scenarios are created by using the current data trends. Any irregular trend in the data in future period may alter the results.
\end{abstract}

Keywords: Short term power market, Sustainability, Discoms, Peak Demand.

\section{INTRODUCTION}

The Indian power sector has witnessed continuous reforms to tackle the inefficiencies in the sector. These inefficiencies have led to the mounting financial losses of the utilities making their business unviable and causing an extra financial burden on the state exchequer. Repeated measures have been undertaken by the central and state governments to improve the financial performance of the power utilities. In 2015, the government of India launched the Ujjwal Discom Assurance Yojna (UDAY) for the financial turnaround and the revival of the state Discoms. The scheme had taken 75 percent of the distribution companies' debt as on $30^{\text {th }}$ September, 2015, being planned as 50 percent during 2015-16 and rest 25 percent in 2016-17 (Ministry of Power, 2015). The scheme is committed to reduce the interest burden of the states from the current 14-15 percent to 8-9 percent. Through the debt the state government have issued non- Statutory liquidity ratio (SLR) state development loan (SDL) bonds in the market. The distribution company debt which was not taken up by the states was converted into bonds and loans with rate of interest of not more than 0.1 percent in addition to the bank base rate. The major reason of the financial losses has been the nonrevision of the tariff by the state governments, in addition to the high cost of supply. The gap between the average revenue and the average cost of supply has widened over the years. The union government has intervened to improve the finances of the utilities 
also through various energy saving schemes. The initiatives like expansion of the energy saving LED (Light emitting diode) lights along with the deployment of solar irrigation pumps have helped the distribution companies. Such schemes prove to be beneficial in improving the finances, however additional measures are required to optimize the finances of the distribution companies.

\subsection{Power finances of Rajasthan}

Rajasthan is the largest state located in the north west of India. The urban centres in the state are very far from each other which poses a challenge for the Discoms to provide their services effectively. The State Electricity Board in Rajasthan had been unbundled into 5 companies in July 2000, namely: (i) Rajasthan Rajya Vidyut Utpadan Nigam Ltd. (ii) Rajasthan Rajya Vidyut Prasaran Nigam Ltd.(iii) Jaipur Vidyut Vitaran Nigam Ltd. (iv) Ajmer Vidyut Vitaran Nigam Ltd. (v) Jodhpur Vidyut Vitaran Nigam Ltd. More than a decade later in 2011-12, the state purchased 52 percent of its power from other states and rest 48 percent was procured from the state generating stations. Out of the total installed capacity in 2011-12, the majority of the power came from thermal power plants (51 percent) followed by hydropower (15 percent), gas (6 percent), nuclear (5 percent) and remaining (23 percent) from other sources. Over the years the transmission and distribution losses of the distribution companies have declined in line with the national average. However at the same time, the gap between the average revenue received and average cost of supply have increased due to supply demand imbalance and inefficiencies on financial parameters. Tamil Nadu, Uttar Pradesh and Rajasthan were the worst performing state utilities quoted by the Ministry of power in 2015. The accumulated loss of Tamil Nadu and Rajasthan in 2015 was ₹12,757 crore and $₹ 12,474$ crore respectively (Ministry of Power 2015).This has been an increasing trend till date in Rajasthan, bankrupting the state Discoms. One major cause for financial ill health has been high power purchase cost which forces the state to take loans from banks which further increase the interest burden on the power distribution utilities.

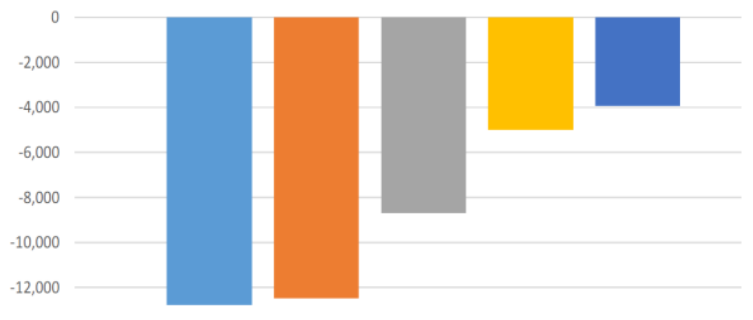

Figure 1: Top Five Loss Making States in India (in crore rupees), 2015. Source: Power Finance Corporation, India

As per the 5th Annual Integrated Rating Report (2017) of the Ministry of power, all the three Discoms of Rajasthan got worst rating among the distribution companies in India. The report cited high cost of power purchase as one of the major reasons for poor performance. The high cost of electricity paved the vicious circle of high cost and inefficiency leading to failure of schemes like UDAY. Thus, this case study seek to develop a strategy for the Rajasthan Discoms to optimize the cost of electricity procured by the Discoms using the digital platforms of the short term power market.

\section{REVIEW OF LITERATURE}

The literature show that short-term power market allows the Discoms to balance supply with demand at all time intervals (Garg, 2020). A financial model built to evaluate the impact of implementing demand side management, on the financial health of Discoms, reflect that planning and managing power demand can optimise the Discoms operations when participating in the short term power market (The Shakti Foundation, 2018). An analysis of competition in the short term power trading from 2008 to 2016 highlights declining prices in the short term power market due to increase in the number of traders in the market. By trading in the short-term market through traders the Discoms can diversify risk and earn more revenues during higher prices, peak-demand hours, and at the same time can purchase electricity at competitive prices with greater transparency (Sharma \& Sharma, 2018, Samanta et al., 2017). Another study evaluating the participation of Rajasthan Discoms in the short term power market during 2008 to 2011, unveils inefficient power planning and procurement strategies in Rajasthan leading to high power purchase cost (Sharma, 2015).

\section{SHORT TERM POWER MARKET}

As per Central Electricity Regulatory Commission (CERC) the "short-term transactions of 
electricity refers to contracts of less than one year period for electricity transacted under bilateral transactions through Inter-state trading licensees (only inter-state part) and directly by the Distribution licensees (also referred as distribution companies or Discoms), Power exchanges- Indian Energy Exchange Ltd (IEX) and Power Exchange of India Ltd (PXIL), and Deviation Settlement Mechanism (DSM)".The short term transactions cater to the short run requirements of electricity caused due to seasonal fluctuations in the demand for electricity in India. Of all instruments of short term power market, in the present analysis transactions on the digital platform of India Energy Exchange are used as a tool to optimize the cost of Discoms. The power exchanges started their operations in India in the year 2008. This provided an automated online platform for electricity trading. These power exchanges have provided flexibility to the participants for sale and purchase of varying quantities of power in different time blocks, thus helping them manage their power requirements more efficiently. Out of the two exchanges, the India Energy Exchange has a majority share (90 percent) in electricity trading and the rest is traded on the Power Exchange of India Limited, hence the transactions done on IEX are considered for the optimisation strategy in the present study.

\subsection{Long term and short term power agreements}

The distribution companies can procure electricity from both long term and short term power agreements based on their requirements. The long term contracts are of the duration ranging from 12-25 years which are signed for a reliable supply of electricity for longer period. The short term power contracts are the transactions of less than 1 year in which power can be purchased from traders, other Discoms and through power exchanges (which does not require any agreement). In long term contracts the distribution companies are required to make right choices in selecting the right set of generators for a reliable source of power. These contracts are for a longer period of time which cannot be terminated. The distribution companies have also to pay the capacity charges to the generators whether they procure electricity or not from the long term contracts signed with them. In short term power market, electricity is available as per demand of the Discoms generally at a rate cheaper than long term power agreements. The emergence of short term power trading has enhanced the efficiency of the utilities as producers also, since with higher cost of generation these would not be able to provide electricity at competitive prices. However, one cannot rely fully on short term power market to fulfil their electricity needs for a longer period of time. The next section envisages the optimal power procurement strategies for the Rajasthan Discoms. The present paper have used the word short term power contracts vis a vis to the trading of electricity at India Energy exchange (i.e. IEX, as it comprises $90 \%$ of total transactions at power exchanges).

\section{BASE DEMAND AND PEAK DEMAND IN RAJASTHAN}

The base demand is the minimum level of electricity needed over a span of time. The peak demand is considered that which is over and above the base demand. The total demand of electricity is the sum of base demand and peak demand. Over the years it can be observed that in Rajasthan, both the base demand and the peak demand have increased (figure 2). The base demand has increased at a coumpound annual growth rate (CAGR) of $8.2 \%$, however the peak demand has increased at $2.8 \%$ annually.

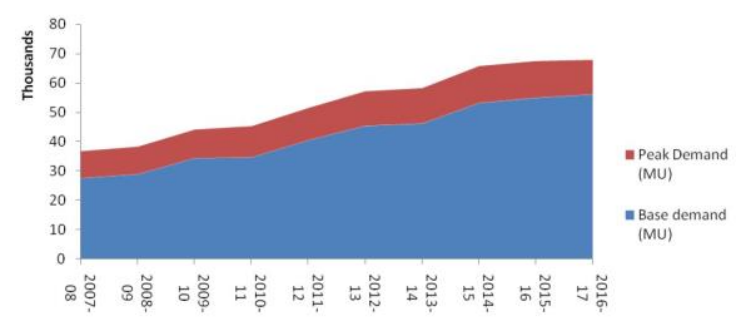

Figure 2: Base and Peak electricity demand in Rajasthan (2007-2017). Source: Central Electricity Authority (CEA), 2007-2017

The Discoms in Rajasthan have not followed a systematic strategy to meet the peak demand of electricity. During 2007-08 to 2016-17, it can be observed from figure 3 that the peak demand has shown an increasing trend, however the peak demand met has not increased correspondingly. This points out to the inefficiencies in the sector to fulfil the demand and supply gaps, leading to high peak unmet. Correspondingly the peak unmet has fluctuated and it shows an uncertain trend (shown on the secondary axis). Due to its uncertainty and wide fluctuations, it is advised to fulfil it by either engaging in short term contracts or participating in the real time market. 


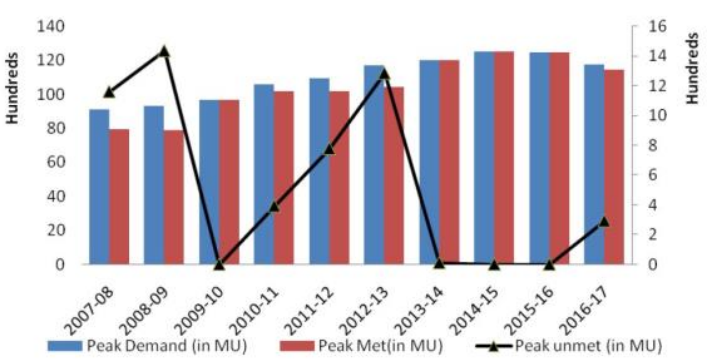

Figure 3: Peak Demand, Peak Met and Peak Unmet (in MU). Source: CEA, 2007-2017

In the past decade, the peak demand has increased at an annual growth rate of $2.8 \%$ and the peak met has increased at a higher growth rate of CAGR of 4.1 percent. The analysis in the present study suggests that though the base demand of electricity should be fulfilled from long term contracts, the peak demand can be realized through the short term market contracts.

\section{COST OPTIMIZATION STRATEGIES}

The main objective of this study is to optimize the power purchase cost of the Discoms. The authors have outlined two strategies and two scenarios have been built in each strategy. In both strategies, the proportion of power demand fulfilled through long term and short term contracts have been designed and compared in such a manner that reduction in power purchase cost can be suggested.

\subsection{Strategy 1}

This strategy is designed whereby the base demand is suggested to be met through long term contracts and the peak demand through short term power market. Thus in the following analysis a comparison of two scenarios is done. In the first scenario the cost of power has been estimated assuming the Discoms fulfills the total demand for the next five years through long term contracts only. In the second scenario, the cost of power has been estimated assuming the total demand for the same period is divided between base demand which is to be fulfilled through the long term contracts, and the peak demand which is to be met through short term contracts.

Thus, in scenario 1 , the total electricity demand of Rajasthan for the next 5 years from 2020 to 2025 is to be met by long term contracts. In scenario 2 , the base demand will be met through long term contracts and the peak demand through engaging in short term power market.
Under the first scenario, the total cost of power through long term contracts during 2020-2025 has been estimated using the projected total demand from 2020 to 2025 [16]. This demand is projected on the basis of electricity demand of Rajasthan in the last decade. The price of electricity taken for the long term contracts is the weighted average which has been estimated from the prices given in the Rajasthan Electricity Regulatory Commission (RERC) tariff order for the year 2016-17 and same is used for the future years.

In second scenario, the base demand of electricity in Rajasthan has been projected on the basis of its growth trajectory of the past decade. The cost of fulfilling the base demand has been estimated using the weighted average price of electricity under a long term contract. Since the balance of the total demand is the peak demand, the price used to estimate the cost of peak demand is the weighted average of IEX prices taken from the CERC report and used for the future years. Table 1 and figure 4 below reflects the two scenarios created in strategy 1.

Table 1: STRATEGY ONE: Cost and the estimated savings in the two scenarios (in million INR), 2020-2025

\begin{tabular}{|l|l|l|l|}
\hline Year & \multicolumn{1}{|c|}{$\begin{array}{c}\text { Estimated } \\
\text { Cost in } \\
\text { Scenario 1 (A) }\end{array}$} & $\begin{array}{c}\text { Estimated Cost } \\
\text { in Scenario 2 } \\
\text { (B) }\end{array}$ & $\begin{array}{c}\text { Savings } \\
\text { (A-B) }\end{array}$ \\
\hline 2020 & 299614 & 287571 & 12043 \\
\hline 2021 & 334043 & 320743 & 13300 \\
\hline 2022 & 347362 & 333059 & 14303 \\
\hline 2023 & 373956 & 358562 & 15394 \\
\hline 2024 & 403498 & 386105 & 17393 \\
\hline 2025 & 435248 & 415854 & 19394 \\
\hline
\end{tabular}

Source: Author's calculation [based on CEA and CERC annual reports data]

The savings estimated here are a result of engaging in short term contracts to meet the peak demand. Hence, it can be suggested that the Discoms should restrict the use of long term contracts for meeting the base demand only, thereby reducing the total cost of power purchase.

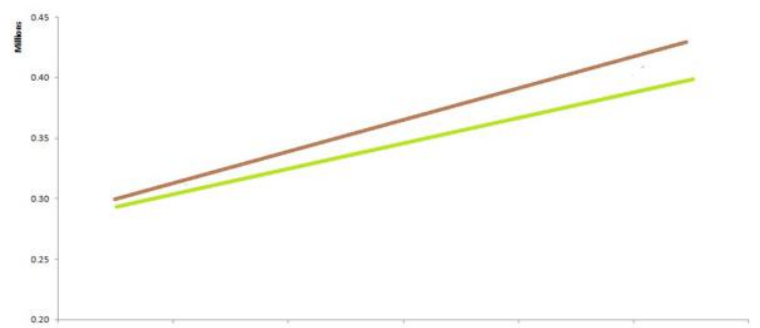

Figure 4: Strategy One: Costs projected under two scenarios (2020-2025) 
There is a visible difference between the costs estimated under the two scenarios and in 2025 both the costs curves diverge and become almost unequal.

\subsection{Strategy 2}

This strategy is designed to compare two scenarios, wherein the first scenario will remain same as the one in strategy 1 , and in the second scenario 90 percent of the demand is estimated to be fulfilled through long term contracts and the balance of 10 percent through the short term market. It is suggested that this 10 percent of the power purchased from short term market should replace the purchases from the generation sources which have high variable cost (appendix 1). To sum up in scenario 1 of this strategy, it has been assumed that the total demand (net generation) is fulfilled by long term contracts, whereas in scenario 2 , it has been assumed that 90 percent of the total power sold to Rajasthan's Discoms is through the long term contracts and the remaining 10 percent demand is met through short term market. Under the second scenario, the power plants that have a variable cost more than INR $3 / \mathrm{KWh}$ should be replaced for meeting the 10 percent of the demand recommended to be met through short term market. Here it has also been assumed that peak demand is around 10 percent of the total power demand.

Therefore, the total cost under the two scenarios has been compared and the net savings estimated for the year 2016-17 in table 2 and figure 5 below. The data source for power demand and long term electricity prices is RERC Annual Revenue Report (ARR) for the year 2016-17.The Short term electricity prices (IEX prices) are taken from CERC annual report on short term power market, 2016-17. Year 2016-17 has been taken for analysis as it has been observed as being a relatively normal year from different parameters enumerated in the reports referred.

Table 2: STRATEGY TWO: Cost and the estimated savings in the two scenarios (in million INR) during 2016-17

\begin{tabular}{|l|c|c|c|}
\hline Year & $\begin{array}{c}\text { Estimated } \\
\text { Cost in } \\
\text { Scenario 1 } \\
(\mathrm{A})\end{array}$ & $\begin{array}{c}\text { Estimated } \\
\text { Cost in } \\
\text { Scenario 2 } \\
(\mathrm{B})\end{array}$ & $\begin{array}{c}\text { Savings } \\
\text { (A-B) }\end{array}$ \\
\hline $2016-17$ & 77309 & 73389 & 3919 \\
\hline
\end{tabular}

Source: Author's calculation (based on RERC and CERC annual reports data)

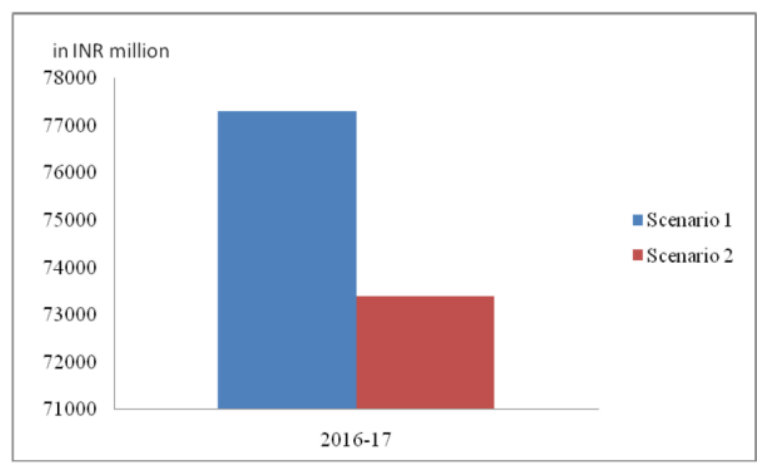

Figure 5: STRATEGY TWO: Comparison of costs in two scenarios (in million INR) during 2016-17

\section{CONCLUSION}

The present paper focuses on developing strategies for optimizing the cost of power procurement by the Discoms in Rajasthan. Since their inception in the year 2008, the power exchanges provide a fully automated online platform for the trading of electricity by the buyers and sellers through market mechanism. The prices on the India Energy Exchange has shown a downward trend, thereby making it attractive for the Discoms to improve their financial balance sheet by participating in short term power purchases. The strategy 1 focuses on how the utilities can enter into a longterm contract for base demand and purchasing the surplus demand from the short term power market. The analysis highlights that this can lead to the accumulated savings over the years and can help the Discoms to maintain fiscal discipline. Strategy 2 recommends the distribution companies to replace the power procured from costly sources (generating sources which have variable cost of above 3 rupees/KWh) with the India Energy Exchange transactions. Both the strategies can play a crucial role in the improvement of the finances of the Discoms in Rajasthan. Other initiatives that can be taken to reduce the cost of power in Rajasthan are: (i) reallocation of costly power; (ii) allocation from cheaper unallocated quota; (iii) advocacy for diversion of coal from inefficient / decommissioned power plants; (iv) advocacy for maximizing indigenous coal usage for Rajasthan generation; (v) advocacy for securing coal from nearer mines to ensure reduction in freight costs. By following the above recommendations the Rajasthan power purchase committee can efficiently reduce the power purchase cost of the Discoms and pave the way for sustainable operation of distribution companies in Rajasthan. 


\section{RELEVANCE OF THE PRESENT STUDY}

The study will guide the policy makers to effectively use the short term power market in the scenario when UDAY scheme bonds are putting extra burden on the state finances and increasing their fiscal deficit. The solution for the Discoms lies in their power procurement strategies which can be remodified as discussed in the paper. In an increasingly digital world, the demand supply gaps can easily be identified on the platforms like IEX (part of short term power market) which can help the Discoms in their sustainable operations.

\section{REFERENCES}

[1] Bhattacharyya SC (2005). The Electricity Act 2003: will it transform the Indian power sector?.Utilities Policy, 13: 260-272.

[2] Girish GP, Vijayalakshmi S(2015). Role of Energy Exchanges for Power Trading in India. International Journal of Energy Economics and Policy, 5(3): 673-676.

[3] Dubbudu R (2016). Electricity Consumption in India.

http://nomoi23.rssing.com/chan12561280/all p108. html. Accessed 15 June 2020.

[4] Ministry of Statistics and Planning, Government of India (2016). Energy Statistics. http://mospi.nic.in /sites /default/ files/publication_reports/Energy_statistics_201 6.pdf. Accessed 15 June 2020.

[5] Sinha P, Mathur K (2016). Empirical Analysis of Developments in the Day-ahead Electricity Markets in India. https://mpra.ub.unimuenchen.de/72969. Accessed 15 June 2020.

[6] Central Electricity Regulatory Commission (2010). CERC (power market) regulations 2010. www.cercind .gov.in. Accessed 15 June 2020.

[7] Girish GP et. al. (2015). Renewable Energy Certificate Trading through Power Exchanges. International Journal of Energy Economics and Policy, 5: 805-808.

[8] Central Electricity Regulatory Commission (2017). Report on Short term Power Market in India: 2016-2017. www.cercind.gov.in. Accessed 15 June 2020.
[9] Thakur T et. al. (2005). Impact assessment of the Electricity Act 2003 on the Indian power sector. Energy Policy, 33: 1187-1198.

[10] Shukla UK, Thampy A (2011). Analysis of competition and market power in the wholesale electricity market in India". Energy Policy, 39: 2699-2710.

[11] Singh A (2006). Power sector reform in India: current issues and prospects. Energy Policy, 34: 2480-2490.

[12] Sharma AK, Sharma D (2018). An Analysis of Competition in Short Term Power Market in India. Review of Integrative Business and Economics Research, 7(s4): 113-130.

[13] Sharma D (2015). Changing Scenario of Indian Electricity Supply Industry: Study of ShortTerm Power Market in India. In: Reddy BS, Ulgiati S (eds). Energy Security and Development, Springer India, 349-360.

[14] Garg V (2020). Deepening India's Short-Term Power Market. https://ieefa.org/wpcontent/uploads/2020/09/Deepening-IndiaShort-Term-Power-Market_September2020.pdf. Accessed 24 April 2021.

[15] Shakti Sustainable Energy Foundation (2018). Analysis of Financial Health of DISCOMs and its Link with End-use Efficiency Implementation. https://shaktifoundation.in/wpcontent/uploads/2018/10 /Analysis-ofFinancial-Health-of-DISCOMs-16Oct18.pdf. Accessed 24 April 2021.

[16] S. Samant, P.K. Mallick, P.K. Pattnaik, J.R. Mohanty, Z. Polkowski, Cognitive Computing for Risk Management, Springer

[17] B. Ghosh, C.K. Panigrahi, S. Samanta, Solar Power in Humanitarian Services: Possibilities, IEEE R10 Humanitarian Technology Conference, (2017) 1-5.

\section{Appendix 1}

Power Purchase Quantum and Cost for FY 201617.

\begin{tabular}{|c|c|c|c|}
\hline $\begin{array}{l}\text { Source of } \\
\text { Power } \\
\text { (Station } \\
\text { wise) }\end{array}$ & $\begin{array}{l}\text { Net } \\
\text { Generat } \\
\text { ion } \\
\text { (MU) }\end{array}$ & $\begin{array}{l}\text { Total } \\
\text { Annu } \\
\text { al } \\
\text { Fixed } \\
\text { charg } \\
\text { es } \\
\text { (Rs }\end{array}$ & $\begin{array}{l}\text { Varia } \\
\text { ble } \\
\text { Cost } \\
\text { (Rs./ } \\
\text { unit) }\end{array}$ \\
\hline
\end{tabular}




\begin{tabular}{|l|l|l|l|}
\hline & & Cr.) & \\
\hline $\begin{array}{l}\text { AURIYA } \\
\text { GTPS }\end{array}$ & 45 & 28 & 3.39 \\
\hline NCTPS 2 & 13 & 3 & 3.03 \\
\hline DULHASTI & 255 & 66 & 3.28 \\
\hline STPS(1 to 6) & 4023 & 345 & 3.32 \\
\hline DCCPP & 95 & 9 & 3.57 \\
\hline RGTP 3 & 936 & 143 & 3.09 \\
\hline MAHI MMH & 1 & 0 & 3.78 \\
\hline MANGROL & 6 & 0 & 3.78 \\
\hline STPS MMH & 2 & 0 & 3.78 \\
\hline $\begin{array}{l}\text { RAPP-V\& } \\
\text { VI }\end{array}$ & 528 & 0 & 3.53 \\
\hline
\end{tabular}

\begin{tabular}{|l|l|l|l|}
\hline RFF & 122 & 0 & 3.99 \\
\hline $\begin{array}{l}\text { Aravali } \\
\text { Power Co. } \\
\text { Pvt. Ltd. }\end{array}$ & 9 & 6 & 4.94 \\
\hline $\begin{array}{l}\text { KarchamWa } \\
\text { ngtoo }\end{array}$ & 412 & 0 & 5.3 \\
\hline $\begin{array}{l}\text { NVVN } \\
\text { Bundled }\end{array}$ & 2406 & 214 & 3.58 \\
\hline Wind farms & 5166 & 0 & 4.98 \\
\hline Solar & 1656 & 0 & 4.61 \\
\hline Biomass & 729 & 0 & 6.64 \\
\hline BHADLA-II & 25 & 0 & 5 \\
\hline
\end{tabular}

Source: Rajasthan Electricity Regulatory Commission ARR 2016-17 